Article

\title{
Conceal Carry and Race: A Test of Minority Threat Theory in Law Generation
}

\author{
Christopher Mullins ${ }^{1, *}$ (i) and Daniel Kavish ${ }^{2}$ \\ 1 Department of Criminology and Criminal Justice, Southern Illinois University, Carbondale, IL 62901, USA \\ 2 Department of Government, Criminology, and Sociology, Lander University, Greenwood, SC 29649, USA; \\ dkavish@lander.edu \\ * Correspondence: mullinsc@siu.edu
}

Received: 25 September 2017; Accepted: 4 December 2017; Published: 12 December 2017

\begin{abstract}
Conceal carry weapon (CCW) laws have generated a great deal of public discussion in the past decades, but little social science attention. Scholarly work on the topic has been focused on finding potential effects of such laws on crime and victimization; little has attempted to explain the trends behind the adoption of the laws. This paper attempts to fill that gap by testing a series of hypotheses grounded in minority threat approaches. Our paper examines whether changes in the racial and ethnic composition of a county predict the voting outcome of Missouri's 1999 conceal-carry referendum. Findings fail to reject the null hypothesis and show the best predictor of the vote within a county was how that county voted in the 2000 Presidential election.
\end{abstract}

Keywords: minority threat; conceal carry laws; Missouri; race and ethnicity

\section{Introduction}

The legal permission to carry concealed weapons $(\mathrm{CCW})$ has garnered much public and media attention over the past decade. All 50 states allow at least some citizens to acquire permits to carry firearms in a concealed manner in public places or allow such behavior without a permit (i.e., AK, VT, and WY). Since 1986, 32 states have changed their laws regarding the carrying of concealed weapons; Alaska has done so twice. All have moved in the direction of a more permissive stance toward the behavior. Academic discourse on the issue has focused on testing the political claims of various sides in the CCW debate; specifically, such work focuses on testing whether or not CCW laws reduce, increase, or have no effect on crime and victimization rates. To date, however, little work has attempted to explain why these laws have been passed.

A great deal of public discourse on the pro-CCW side emphasizes the need to protect one's self and family from criminal victimization (see Melzer 2009). While the argument is clearly part of a broader and well-crafted political discourse to sway public opinion, at some level we assume that people who support CCW laws and who accept and repeat this discourse do so out of a genuinely felt desire for self-protection. Regardless of their actual victimization risk, which is well known to be disconnected from perceived victimization risk (Chadee et al. 2007; Slovic et al. 1982; Wilson-Doenges 2000), at some level victimization avoidance drives the discourse and thus, potentially, the voting behavior of supporters.

This paper is specifically interested in one case of legal transformation from may issue to shall issue; in 1999, MO held a statewide referendum on the issue which narrowly failed. The vote broke down on urban/rural lines, with rural voters overwhelmingly in support, urban strongly against. The failure of Proposition B was in fact due to higher than usual urban voter turnout (Pierce 2006). In 2003, the legislature passed a bill shifting the law to shall issue, and then over-rode an ensuing gubernatorial veto. The law was then upheld by the state's Supreme Court (Pierce 2006) Moore et al., 
and Shepard et al. V. Madigan $2012^{1}$. The Missouri case gives us the opportunity to look at the 1999 voting results on a county by county basis and to examine whether these results are associated with minority population or changes in minority population. To examine this, we use county level data to see whether the racial and ethnic composition, or changes in racial and ethnic composition, predict how the county voted on the 1999 CCW ballot initiative. Due to the nature of our data, this should be seen as more of an exploratory examination on potential relationships between variables of interest, and not a set of strictly causal claims.

\section{Literature Review}

Fear of crime and perceptions of neighborhood safety have been empirically linked with perceived or actual minority composition of a local population, especially African American population (Chiricos et al. 1997, 2001; Liska et al. 1982; Moeller 1989; Skogan 1995; Taylor and Covington 1993; Thompson et al. 1992) as have changes in a region's composition (Taylor and Covington 1993). This is not surprising due to the profound tendency in the USA to equate racial and ethnic minorities, especially young Hispanic and African-American males, with violence and crime. This stereotype is held by all racial and ethnic groups in the USA, including Hispanics and African-Americans, and is often explained by the media's saturation with images of young Black male offenders (Barak 1994; Bing 2010).

If racial composition of an area, or changes in racial composition of an area, influence fear of crime or perceived victimization risk, then it is possible that they would also influence other attitudes and voting behaviors, especially those concerning firearms. The connection between weapon carrying and victimization avoidance is strong among both lawful citizens (Bankston and Thompson 1989; Bankston et al. 1990; Young 1986) and criminally active ones (Jacobs 2000; Jacobs and Wright 2009). If a portion of the community feels threatened, and perceives its victimization risk as increasing, then support for CCW laws should be elevated. Theoretically, this process is best represented in the tenants of minority threat models. Liska and Yu (1992), suggested that social threat is conceived of in terms of threats to personal safety and personal values. Likewise, Winfree and Abadanski (2017, p. 168) attest that the "specific nature" perceived minority threat manifests itself in a variety of ways. Thus, one-way perceived minority threat may manifest itself is in voting behavior.

Minority threat models of social control suggest that incarceration rates and policing practices are driven by a majority group's desire to exert social control on a minority group. Such propositions have been widely tested in relation to pretrial release (Free Jr. 2004; Nagel 1983), sentencing (Bontrager et al. 2005; Feldmeyer and Ulmer 2011; Jacobs and Carmichael 2002; Ruddell and Urbina 2004; Stolzenberg et al. 2004; Wang 2012; Wang and Mears 2010), the size of police forces (Chamlin 1989; Stults and Baumer 2007), arrest (Chamlin and Liska 1992; Liska and Chamlin 1984; Parker et al. 2005) and police use of deadly force (Liska and Yu 1992).

Chiricos and his colleagues (Chiricos et al. 1997) examined whether fear of crime was influenced by racial composition or perceptions of racial composition. Their results showed that perceptions of racial composition influence fear of crime, but that actual racial composition had no effect on the fear of crime. That is not to say that actual racial compositions are of no consequence. Rather, their findings merely suggest that perceptions of racial composition may be more predictive of fear of crime than actual racial compositions of a given place Taylor (1998) found that whites' attitudes vary with region, specifically increases in the local Black population resulted in an increase to traditional prejudice. However, this effect was only seen among non-southern whites. Chiricos et al. (2001) found that perceptions of both Blacks and Hispanics living nearby increased perceived risk of victimization based on regional location as well, but in a smaller geographic context. When looking at specific racial or ethnic subsamples, the precise effect was conditioned on whether the person lived in south

1 Moore et al., and Shepard et al. V. Madigan. 3.11-cv-3134-SEM-BCC and 3:11-cv-405-WDS-PMF (7th Circuit 2012). 
Florida. Outside of south Florida, whites did not associate minority presence with increased risk, Blacks associated Hispanics with increased risk and Hispanics associated both Blacks and Hispanics with increased risk. In south Florida, minorities did not see minority presence as increasing risk, but whites did - a finding that the authors attribute to racial threat and the fact that whites are no longer the majority population in the region.

Fear of crime is not the only outcome examined by threat perspectives. Others have attempted to explain the existence or absence of the death penalty using racial composition measures as predictors. Jacobs and Carmichael (2002) conducted a pooled time-series analysis of the death penalty and found significant support for both "threat" and "political" explanations for jurisdictional decisions concerning the death penalty. Chiricos, Welch, and Gertz (Chiricos et al. 2004) examined whether support for harsh and strict policies toward crime was related to the racial typification of crime. They found that racial typification of crime was a significant predictor of policy punitiveness. Shortly thereafter, Bontrager et al. (2005) used the racial threat perspective to guide their examination of the effect of race and ethnicity on the withholding of adjudication. The results of their analyses showed that Hispanics and Blacks are significantly less likely than whites to have adjudication withheld when other individual and community level factors are controlled for.

Thus, the extant literature does provide support for perceptions of changes in minority populations producing changes in citizen-level attitudes and in criminal justice system behaviors. Our current interest in potential effects on changes in law making behavior is not without out precedent in the literature. Two studies on Louisiana voting patterns reveal a potential impact of changes in African-American populations on white voting patterns (Giles and Buckner 1988; Giles and Hertz 1994). A few studies have looked at changes in laws, specifically those related to welfare policies (Chamlin 1992; Chamlin et al. 2007), but work on minority threat models predicting changes in laws themselves has been less developed. We hope to extend that line of work here. We argue here that CCW laws respond to the same perceived racial and ethnic threats other scholars have examined. However, instead of a criminal justice response, these changes in laws allow citizens to modify their own behavior to make themselves feel safer.

Currently, there are three forms laws governing CCW may take: May Issue laws, Shall Issue laws, and unrestricted carrying of concealed weapons (Cramer and Kopel 1995; Kranz 2006). The most restrictive form is May Issue laws. Here the ability to grant a citizen's request is left up to a state or local official (typically a county sheriff or the like), thus the official "may issue" a permit if they decide the applicant has merit. Most states adopted May Issue laws in the early part of the 20th century (Cramer and Kopel 1995), though most states severely restricted the number of permits issued and to whom they were given (i.e., Judges, politicians or their body guards, etc.). Since the 1980s, many states have changed their laws from May Issue to Shall Issue. Shall Issue laws require that a permit be given to an applicant if they meet a set of conditions established in the law; the issuing body has no discretion. The most permissive form of regulation is found in states which allow unrestricted carrying of concealed weapons, i.e., one does not need a special permit to do so. Currently, threestates have such laws. The legislatures of Alaska and Wyoming changed their statutes in the mid-1990s; Vermont has had no restrictions since a 1903 state supreme court ruling interpreting the right to bear arms very broadly (Cramer and Kopel 1995; Kranz 2006).

The bulk of the literature on concealed carry laws addresses their effects; few examine the adoption of less restrictive of handgun laws. Those that do exist are found within the field of economics and are grounded in the theoretical assumptions of that discipline. Grossman and Lee (2008) found that only percentage of the state population residing in an urban area and the behavior of neighboring states were significant predictors of changing laws. Mixon and Gibson (2001) used logit regression to predict the changing of laws from May Issue to Shall Issue status in a national sample. While their main interest was the state of property rights laws and political interest groups, they did include a measure of the percent of the state population which was African American, which was negatively related to retaining May Issue laws (e.g., positively related to changing to Shall Issue laws), but was 
not statistically significant. Number of death row prisoners was similarly related to retention of May Issue laws and was significant, as was degree of urbanization. Ratio of state legislature controlled by the Republican party was negatively and significantly related to retaining May Issue laws while the ratio of legislators that were female was positively and significantly related to retaining May Issue laws. Maximum likelihood regressions of that same data and hypotheses produced highly similar results (Mixon Jr. and Gibson 2002).

Taken as a group, these three studies highlight the potential role of certain social and demographic factors that may predict the changing of handgun laws. Not surprisingly, urban populations seem to favor more restrictive handgun laws, something that general studies of attitudes and use of firearms has long established (see Bankston et al. 1990; Young 1986). Similarly unsurprising is the fact that state legislators dominated by the Republican party are more likely to change their laws; the Republican party's support of this issue is long standing. However, since the 1990s, suburban and rural Democrats have held similar positions. The findings concerning policing expenditures and size of the African American population run counter to a threat theory's predictions. We suggest that the social forces behind minority threat models are locally-orientated and the use of state-level data masks quite a bit of variation.

While we may not yet know a lot about why handgun laws change, we do know quite a bit about why people carry guns. The GSS has long asked questions about gun ownership and use, for example, as have other surveys. Much research on why individuals carry weapons establishes that risk reduction or victimization avoidance is often a central motivation. Specifically, women resort to gun carrying out of "fear of crime" (Young 1986), men by a "desire to thwart victimization" (Bankston et al. 1990, p. 298). The differences here may be more than semantic and are likely response to the same social stimuli. Stroud (2012, pp. 230,233) interviews of men with CCW permits found that nearly all of her respondents claimed their weapon carrying was to better allow them to defend their families; her respondents over 40 also indicated the need for self-defense was key to their carrying behaviors. In addition, directly related to our research question here, if an interviewee did not claim to carry the weapon all the time, they did carry it when they went to places they had not been before, traveled out of town, or went to certain parts of town "with a reputation for being dangerous" - a concept that Stroud found was heavily racialized. In fact, only one of her interviewees "resisted racist constructions of threat". O'Neill (2007) and Melzer (2009) in separate analysis of the NRA's discourse about the need and use of personal firearms ownership found similar themes.

This work reinforces the conceptual utility of thinking about race and ethnic diversity as driving attitudes about firearms and the desire or need to carry them. We think minority threat approaches (also called power, racial or ethnic threat) provide sound theoretical propositions to explore this dynamic. The basic premise of this approach is that social factors or behaviors may be influenced when minority groups appear to pose a power or economic threat to the majority group (Blaylock 1967). Drawing upon the base tenants of a minority threat model to explore relationships between demographic change and voting behavior yields the following hypotheses:

Hypothesis 1. Counties that experienced an increase in African-American and Hispanic population between 1990 and 2000 were more likely to vote in favor of passing the 1999 CCW law.

Hypothesis 2. Counties with a larger portion of their population in urban areas were less likely to vote in favor of passing the 1999 CCW law.

Hypothesis 3. Counties with an increase in reported crime were more likely to vote in favor of passing the 1999 CCW law. 


\section{Materials and Methods}

\subsection{Data}

The current study utilizes data from several sources to compile the county-level measures necessary for our analyses. Census data were used to examine county-level characteristics, including the proportion of African-American and Hispanic residents, proportion receiving public assistance, median income, etc. (see below for more details on the specific measures used). The 1990 and 2000 censuses were used so that changes in some of these characteristics could be assessed as well, something of particular interest for this project since one of our main questions is whether increases in minority populations increase support for CCW laws. To estimate actual crime rates, data from the FBI's Uniform Crime Report (UCR) were used. Finally, data were obtained from the Missouri Secretary of State's office, containing county-level information on what proportion of voters voted in support of or in opposition to Missouri's CCW law in 1999 and on what proportion of individuals voted for George W. Bush in the 2000 presidential election. Our analytic sample is comprised of all 114 counties in Missouri, plus St. Louis city, for a total $\mathrm{N}$ of 115 . St. Louis city is politically independent of any county, and is treated as a separate county of its own by both the US Census and the UCR. This project follows that convention and treats St. Louis city as its own "county".

\subsection{Focal Measures}

Proportion Voting Yes: The dependent variable indicates what proportion of voters in the county that voted "Yes" for the CCW ballot initiative.

Change in African-American Population: One of the focal independent variables indicates whether there was an actual change in the proportion of African-Americans in the county between the 1990 and 2000 censuses. A change of zero would indicate a constant proportion (i.e., no change), while a negative number would indicate a decrease in the proportion of African-Americans, and a positive number would indicate an increase (range: $-1-1$ ).

Change in Hispanic Population: Another similar focal independent variable indicates whether there was an actual change in the proportion of Hispanics in the county between the 1990 and 2000 censuses. A change of zero would indicate a constant proportion (i.e., no change), while a negative number would indicate a decrease in the proportion of Hispanics, and a positive number would indicate an increase (range: $-1-1$ ).

Reported Crime: Another main variable that must be examined is the actual crime rate per 100,000 of any given county. Although crime is underreported to the police, county-level victimization data are not available, thus we use the UCR to find the 2000 crime rate for each county. Our measure combines both violent and property crimes.

Rural-Urban Continuum: Because Missouri's votes reflected a clear urban/rural distinction, it is necessary to control for this factor as well. County-level organizational data were added to the analysis as an important variable to supplement the existing data. Missouri 2003 rural-urban continuum (RUC) scores were matched with the appropriate counties. The 2003 scores range from 1 to 9 . The initial scores were reverse coded so that scores of 7,8, or 9 represent an urban county. A score of 9 represents the most urban possible score available. St. Louis County is an example of a county that would have a RUC score of 9. RUC scores of 3 or lower indicate more rural counties and scores of 4, 5, or 6 indicate suburban counties. A score of 1 represents the most rural score possible. Essentially, a higher continuum score represents a larger metropolitan area and a lower continuum score represents a more rural area.

RUC-Urban: Urban counties, or those counties with rural-urban continuum scores of 7, 8, or 9, are juxtaposed with the other counties using a dichotomous variable. Counties with rural-urban continuum scores of 7,8 , or 9 were coded as urban (urban $=1$ ). 
RUC-Suburban: Likewise, suburban counties, or those counties with rural-urban continuum scores of 4,5 , or 6 , are contrasted with the other counties using a dichotomous variable. Counties with rural-urban continuum scores of 4, 5, or 6 were coded as suburban (suburban $=1$ ).

RUC-Rural: Rural counties, or those counties with rural-urban continuum scores of 1, 2, or 3, are contrasted with the other counties using a dichotomous variable. Counties with rural-urban continuum scores of 1,2 , or 3 were coded as rural (rural $=1$ ).

\subsection{Controls}

Other county-level characteristics will be used as controls as well, although their role is not anticipated to be as central as the measures discussed above. General demographic controls such as the proportion male, and median income are included, as well as more detailed measures such as the proportion of individuals receiving public assistance. All of these measures are taken from the 2000 census. To control for the political climate of the county, the proportion of individuals that voted for George W. Bush in the 2000 presidential election will also be used as an important control variable. The election data are publicly available from the Missouri Secretary of State.

\subsection{Analytic Approach}

First, descriptive statistics are presented, followed by the results of the multivariate analyses. Since the outcome examined is a proportion, for multivariate analyses, OLS regressions are used to assess how the predictors impact the proportion of voters voting in support of the CCW law. Such analysis is appropriate as there is adequate variation on our variables, none are significantly skewed, and multicollinearity is not an issue (diagnostic statistics available upon request).

\section{Results}

Findings

Table 1 presents descriptive statistics for our variables. The mean proportion of Missouri voters per county that voted in support of the CCW measure was 0.633 . The proportional county vote mean shows a difference from the overall vote total due to size differences in Missouri counties, with the St. Louis and Kansas City metropolitan areas having much more populace counties than the rest of the state. Nearly $30 \%$ of the counties were urban, about $26 \%$ were suburban, and roughly $44 \%$ were rural. We can see that between 1990 and 2000, counties on average experienced an increase of about $0.8 \%$ in the number of Black residents and an increase of about $0.8 \%$ in the number of Hispanic residents. In 2000, we also see that the average reported county crime rate was 148.28 crimes per 100,000 population; however, the large standard deviation reveals that the reported crime rates varied greatly, with some counties experiencing more crime than others.

Table 2 shows the results of the OLS regression models estimated to predict the proportion of voters that voted in support of the CCW measure. Model 1 used the rural-urban continuum variable. This initial regression model showed that this measure significantly contributed to the proportion of voters that voted in support of CCW laws. The findings of this model indicate that support for CCW laws decreased in more urban counties. None of the other focal independent variables were found to have significantly contributed to the model. However, support for CCW laws significantly increased in counties with higher proportions of individuals on public assistance, higher proportions of individuals that voted for Bush, and higher proportions of male residents.

Model 2 includes all of the variables included in Model 1, but a binary measure of urban versus non-urban counties is used rather than using the rural-urban continuum variable. Again, changes in minority populations still were not shown to be significantly related to the proportion of voters voting in support of CCW laws. Likewise, the reported crime rate was not significantly predictive of CCW law support. Model 2 clearly shows that there was significantly less support for CCW laws in urban counties than in non-urban counties. Once more, support for CCW laws significantly increased in 
counties with higher proportions of individuals on public assistance, higher proportions of individuals that voted for Bush, and higher proportions of male residents.

Table 1. Descriptive Statistics of Dependent and Independent Variables ( $\mathrm{N}=115)$.

\begin{tabular}{|c|c|c|c|c|}
\hline Variables & Minimum & Maximum & Mean or $\%$ e & Std. Dev. \\
\hline \multicolumn{5}{|l|}{ Dependent Variable } \\
\hline Proportion voted "Yes" & 0.259 & 0.832 & 0.633 & 0.101 \\
\hline \multicolumn{5}{|l|}{ Focal Variables } \\
\hline Change in Prop. Blacka & -0.131 & 0.177 & 0.008 & 0.033 \\
\hline Change in Prop. Hispanic ${ }^{a}$ & -0.016 & 0.093 & 0.008 & 0.015 \\
\hline 2000 Reported Crime ${ }^{d}$ & 0 & 4008.760 & 148.281 & 376.521 \\
\hline 2003 RUC & 1 & 9 & 4.383 & 2.799 \\
\hline RUC-Urban & 0 & 1 & $29.57 \%$ & 0.458 \\
\hline RUC-Suburban & 0 & 1 & $26.09 \%$ & 0.441 \\
\hline RUC-Rural & 0 & 1 & $44.35 \%$ & 0.499 \\
\hline \multicolumn{5}{|l|}{ Control Variables } \\
\hline Prop. Male ${ }^{b}$ & 0.451 & 0.620 & 0.491 & 0.019 \\
\hline Median Income (in 1000's) ${ }^{b}$ & 5.620 & 73.570 & 27.348 & 13.732 \\
\hline Prop. on Public Assistance b & 0.005 & 0.039 & 0.015 & 0.006 \\
\hline Prop. Voted "Bush" c & 0.199 & 0.715 & 0.577 & 0.073 \\
\hline
\end{tabular}

a Comparing change between the 1990 \& 2000 censuses; $^{\mathrm{b}}$ Taken from 2000 census; $^{\mathrm{c}}$ Taken from 2000 election results; ${ }^{\mathrm{d}}$ Rate per 100,000 population; e \%'s may not equal $100 \%$ due to rounding.

Table 2. Coefficients (SE) of Regressions Predicting Proportion of Votes in Favor of CCW Passage.

\begin{tabular}{|c|c|c|c|c|c|c|c|c|c|c|c|c|c|c|c|c|}
\hline \multirow[t]{2}{*}{ Variables } & \multicolumn{4}{|c|}{ Model 1} & \multicolumn{4}{|c|}{ Model 2} & \multicolumn{4}{|c|}{ Model 3} & \multicolumn{4}{|c|}{ Model 4} \\
\hline & B & SE & \multicolumn{2}{|c|}{ Beta } & B & SE & \multicolumn{2}{|c|}{ Beta } & B & SE & \multicolumn{2}{|c|}{ Beta } & B & SE & \multicolumn{2}{|c|}{ Beta } \\
\hline Change in Prop. Black ${ }^{a}$ & -0.348 & 0.258 & -0.114 & & -0.404 & 0.263 & -0.132 & & -0.448 & 30.266 & -0.146 & $t$ & -0.372 & 0.258 & -0.121 & \\
\hline Change in Prop. Hispanic a & -0.003 & 0.466 & 0.000 & & -0.113 & 0.475 & -0.017 & & -0.127 & 70.483 & -0.019 & & 0.094 & 0.472 & 0.014 & \\
\hline 2000 Reported Crime ${ }^{\mathrm{d}}$ & 0.000 & 0.000 & 0.008 & & 0.000 & 0.000 & -0.020 & & 0.000 & 0.000 & 0.000 & & 0.000 & 0.000 & 0.016 & \\
\hline 2003 RUC & -0.010 & 0.003 & -0.272 & ** & & & & & & & & & & & & \\
\hline RUC Urban & & & & & -0.035 & 0.018 & -0.160 & t & & & & & & & & \\
\hline $\begin{array}{l}\text { RUC Suburban } \\
\text { RUC Rural }\end{array}$ & & & & & & & & & -0.015 & 50.017 & -0.064 & & 0.052 & 0.018 & 0.258 & ** \\
\hline \multicolumn{17}{|l|}{ Control Variables } \\
\hline Prop. Male ${ }^{b}$ & 0.702 & 0.363 & 0.135 & $t$ & 0.736 & 0.374 & 0.141 & + & 0.653 & 0.376 & 0.125 & + & 0.786 & 0.366 & 0.151 & *** \\
\hline Median Income (in 1000's) ${ }^{b}$ & 0.000 & 0.001 & -0.050 & & 0.000 & 0.001 & 0.030 & & 0.001 & 0.001 & 0.069 & & 0.000 & 0.001 & -0.042 & \\
\hline Prop. on Public Assistance b & 7.388 & 1.465 & 0.429 & $* * *$ & 8.269 & 1.454 & 0.480 & $* * *$ & 9.347 & 1.357 & 0.542 & $* * *$ & 7.654 & 1.431 & 0.444 & $* * *$ \\
\hline Prop. Voted "Bush" c & 0.689 & 0.108 & 0.497 & $* * *$ & 0.717 & 0.111 & 0.517 & $* * *$ & 0.792 & 0.110 & 0.571 & $* * *$ & 0.751 & 0.105 & 0.541 & $* * *$ \\
\hline$R^{2}$ & \multicolumn{4}{|c|}{0.533} & \multicolumn{4}{|c|}{0.511} & \multicolumn{4}{|c|}{0.497} & \multicolumn{4}{|c|}{0.532} \\
\hline
\end{tabular}

Model 3 includes all previous variables from Model 2, but instead of contrasting urban and non-urban counties, this model contains a binary measure of suburban versus non-suburban counties. The addition of this variable significantly changed the outcomes observed in the previous model. The findings of this model indicate that support for CCW laws in suburban counties is not significantly different from support for CCW laws in non-suburban counties. Proportional changes of Hispanic populations were shown, once again, to not be significantly related to support of CCW laws. However, Proportional changes of Black populations were shown to be significantly related to the proportion of voters voting in support of CCW laws, albeit at a low magnitude. Reported crime rates were still not significant in predicting CCW law support. Again, support for CCW laws significantly increased in counties with higher proportions of individuals on public assistance, higher proportions of individuals that voted for Bush, and higher proportions of male residents.

Model 4 includes all previous variables from Model 3, but instead of contrasting suburban and non-suburban counties, this model contains a binary measure of rural versus non-rural counties. 
Model 4 clearly shows that there was significantly more support for CCW laws in rural counties than in non-rural counties. In the current model, increases in the proportion of minority residents were not significantly related to the support of CCW laws. Similar to every previous model, reported crime rates were not significant in predicting CCW law support. Finally, support for CCW laws significantly increased in counties with higher proportions of individuals on public assistance, higher proportions of individuals that voted for Bush, and higher proportions of male residents.

\section{Discussion}

This paper has explored the potential relationship between changes in the size of racial and ethnic minority populations and support for conceal carry laws. Drawing on Minority Threat perspectives, we extend this approach to apply to law making, specifically public referenda, using the Missouri 1999 referendum as a case. We predicted that counties with larger increases in the size of racial and ethnic majorities would have a larger number of "yes" votes in the CCW referendum. We also hypothesized that counties with an increase in crime would have more "yes" votes and that urban counties would have fewer "yes" votes.

Due to the outcomes in our models, we fail to reject the null hypothesis for Hypothesis 1. In fact, we found some evidence counter to the predictions made by that hypothesis. Changes in the size of the Hispanic population never attained statistical significance, but in rural areas the relationship was in the direction predicted by a minority threat approach. Changes in the size of the Black population was consistently in the opposite direction and did attain statistical significance in suburban and other moderately urbanized counties. This negative relationship between minority population change and voting behavior is likely an artifact of other social processes occurring at the time. Both Kansas City and Saint Louis were experiencing a new wave of white flight; whites were moving from the inner ring suburbs to the other ring suburbs and African Americans were moving from the urban core to the inner ring suburbs. African Americans generally opposed CCW laws and their voting behavior would further reinforce a negative relationship.

Hypothesis 2 was confirmed. As other work has shown, a key factor driving voting behavior at the county level was the degree of urbanization and the predominant political ideology in the county. There was far more support for the proposition in more rural areas. This reflects the long standing political differences between urban and rural areas in the state as well as the specific divide on firearms between urban and rural populations. Our analyses confirm the existence of two gun cultures in Missouri; one urban, one rural. However, unlike Grossman and Lee (2008), but similar to Mixon and Gibson (2001, 2002), we found that political party association was strongly predicted voting on the CCW issue, more so than the urbaneness of the county. Reported crime did not attain significance in our analyses. Thus, even though many people cite "protection" as a reason for wanting to carry a concealed firearm, the real threat of criminal victimization had no effect on voting behavior.

There are several limitations to our study. First, we use an objective measure of changes in minority population. Several papers have shown that such data often have no relation to individual perception of the size of minority populations, and the subjective measure of perceived size is strongly predictive of fear of crime and perceptions of social disorder (Chiricos et al. 1997, 2001). Similarly, a better measure of fear of crime would have been an individual-level measure of perceived crime rates or fear of crime as individuals are not necessarily aware of the objective amount of crime in their communities (Chiricos et al. 1997). Second, in many Missouri urban and rural counties, there is little change in minority population size between 1990 and 2000. Most of the population changes occurred in suburban Kansas City and Saint Louis, representing only a handful of counties in the state. Third, county may be too large of a geographic aggregation to detect the hypothesized effects; one might not be aware of demographic forces operating county wide, but rather, one's perceptions may be limited to a smaller level of aggregation. Neighborhood would be a better unit of analysis, but voting data were only available by county. 
A further limitation is our reliance on 2000 Census and Presidential voting data. The vote of interest took place in 1999, a year after the collection of much of our data. These data were used as they were available. We did not have measures of the critical indicators from 1999 (not from any other point in the 1990s after 1990 itself). However, there is nothing to indicate a significant change in crime, population demographics, or voting behavior between 1999 and 2000.

\section{Conclusions}

While we did not find broad support for a minority threat explanation for law making, we do not necessarily believe that it is an unproductive line for future research. Our data are crude and many important indicators measured by proxies. If social forces surrounding changes in minority population sizes influence the behavior of the criminal justice system, those same forces should influence the laws that are made as well, whether by legislative bodies or referenda. Hopefully future studies will address some of the methodological short comings of this study by measuring individual level perceptions of crime and changes in minority populations as well as attitudes towards CCW laws as well as the desire to carry a concealed weapon.

Acknowledgments: This research was not supported by external or internal funding.

Author Contributions: Christopher Mullins conceived and designed the project, and wrote the introductory materials as well as the discussion, with input from Daniel Kavish. Daniel Kavish cleaned and analyzed the data, and wrote the findings section, with input from Christopher Mullins. The methods section and all revisions were done jointly.

Conflicts of Interest: The authors declare no conflict of interest.

\section{References}

Bankston, William B., and Carol Y. Thompson. 1989. Carrying Firearms for Protection: A Causal Model. Sociological Inquiry 59: 75-87. [CrossRef]

Bankston, William, Carol Y. Thompson, Quentin A. L. Jenkins, and Craig J. Forsyth. 1990. The Influence of Fear of Crime, Gender, and Southern Culture on Carrying Firearms for Protection. The Sociological Quarterly 31: 287-305. [CrossRef]

Barak, Gregg. 1994. Between the waves: Mass-mediated themes of crime and justice. Social Justice 21: $133-47$.

Bing, Robert. 2010. Race, Crime and the Media. New York: McGraw Hill.

Blaylock, H. 1967. Status Inconsistency, Social Mobility, Status Integration and Structural Effects. American Sociological Review 32: 790-801. [CrossRef]

Bontrager, Stephanie, William Bales, and Ted Chiricos. 2005. Race, Ethnicity, Threat and the Labeling of Convicted Felons. Criminology 43: 589-622. [CrossRef]

Chadee, Derek, Liz Austen, and Jason Ditton. 2007. The relationship between likelihood and fear of criminal victimization: Evaluating risk sensitivity as a mediating concept. British Journal of Criminology 47: 133-53. [CrossRef]

Chamlin, Mitchell B. 1989. A Macro Social Analysis of Change in Police Force Size, 1972-1982: Controlling for Static and Dynamic Influences. Sociological Quarterly 30: 615-24. [CrossRef]

Chamlin, Mitchell B. 1992. Intergroup Threat and Social Control: Welfare Expansion among States during the 1960s and 1970s. In Social Threat and Social Control. Edited by Allen E. Liska. Albany: SUNY Press, pp. 62-74.

Chamlin, Mitchell B., and Allen E. Liska. 1992. Social structure and crime control revisited: The declining significance of intergroup threat. In Social Threat and Social Control. Edited by Allen E. Liska. Albany: SUNY Press, pp. 103-12.

Chamlin, Mitchell B., Melissa W. Burek, and John K. Cochran. 2007. Welfare Policy as Social Control: A Specific Test of the Piven and Cloward Thesis. Criminal Justice Policy Review 18: 132-52. [CrossRef]

Chiricos, Ted, Michael Hogan, and Marc Gertz. 1997. Racial Composition of Neighborhood and Fear of Crime. Criminology 35: 107-31. [CrossRef]

Chiricos, Ted, Ranee McEntire, and Marc Gertz. 2001. Perceived racial and ethnic composition of neighborhood and perceived risk of crime. Social Problems 48: 322-40. [CrossRef] 
Chiricos, Ted, Kelly Welch, and Marc Gertz. 2004. Racial typification of crime and support for punitive measures. Criminology 42: 358-90. [CrossRef]

Taylor, Ralph B., and Jeanette Covington. 1993. Community Structural Change and Fear of Crime. Social Problems 40: 374-97. [CrossRef]

Cramer, Clayton E., and David B. Kopel. 1995. "Shall Issue": The New Wave of Concealed Handgun Permit Laws. Tennessee Law Review 62: 679-747.

Feldmeyer, Ben, and Jeffery T. Ulmer. 2011. Racial/ethnic threat and Federal Sentencing. Journal of Research in Crime and Delinquency 48: 238-70. [CrossRef]

Free Jr., Marvin D. 2004. Bail and Pretrial Release Decisions: An Assessment of the Racial Threat Perpsective. The Journal of Ethnicity in Criminal Justice 2: 23-44. [CrossRef]

Giles, Michael W., and Melanie A. Buckner. 1988. David Duke and Black Threat: An Old Hypothesis Reexamined. The Journal of Politics 55: 702-13. [CrossRef]

Giles, Micheal W., and Kaenan Hertz. 1994. Racial Threat and Partisan Identification. American Political Science Review 88: 317-26. [CrossRef]

Grossman, Richard S., and Stephen A. Lee. 2008. May Issue versus Shall Issue: Explaining the Pattern of Concealed-Carry Handgun Law, 1960-2001. Contemporary Economic Policy 26: 198-206. [CrossRef]

Jacobs, Bruce A. 2000. Robbing Drug Dealers. Hawthrone: Aldine de Gruyter.

Jacobs, David, and Jason T. Carmichael. 2002. The Political Sociology of the Death Penalty: A Pooled Time-Series Analysis. American Sociological Review 67: 109-31. [CrossRef]

Jacobs, Bruce A., and Richard Wright. 2009. Street Justice: Retaliation in the Criminal Underworld. New York: Cambridge University Press.

Kranz, Steven W. 2006. A Survey of State Conceal and Carry Statutes: Can Small Changes Help Reduce the Controversy? Hamline Law Review 29: 637-707.

Liska, Allen E., and Mitchell B. Chamlin. 1984. Social Structures and Crime control among macrosocial units. American Journal of Sociolgy 90: 388-426. [CrossRef]

Liska, Allen E., Joseph J. Lawrence, and Andrew Sanchirico. 1982. Fear of Crime as a Social Fact. Social Forces 60: 760-71. [CrossRef]

Liska, Allen, and Jiang Yu. 1992. Specifying and Testing the Threat Hypothesis: Police Use of Deadly Force. In Social Threat and Social Control. Edited by Allenn Liska. Albany: Staute University of New York Press, pp. 53-70.

Melzer, Scott. 2009. Gun Crusaders: The NRA's Culture War. New York: New York University Press.

Mixon, Franklin G., and M. Troy Gibson. 2001. The retention of state level concealed handgun laws: Empirical evidence from interest group and legislative models. Public Choice 107: 1-20.

Mixon Jr., Franklin G., and M. Troy Gibson. 2002. Simultaneous estimation of complementary political economic models: An application to concealed carry handgun legislation. Applied Economic Letters 9: 265-70. [CrossRef]

Moeller, Gertrude L. 1989. Fear of criminal victimization: The effect of neighborhood racial composition. Sociological Inquiry 59: 208-21. [CrossRef]

Nagel, Ilene H. 1983. The Legal/Extra-Legal Controversy: Judicial Decisions in Pretrial Release. Law and Society Review 17: 481-515. [CrossRef]

O'Neill, Kevin Lewis. 2007. Armed Citizens and the Stories They Tell: The National Rifle Association's Achievement of Terror and Masculinity. Men and Masculinities 9: 457-75.

Parker, Karen F., Brian J. Stults, and Stephen K. Rice. 2005. Racial Threat, Concentrated Disadvantage and Social Control: Considering the Macro-Level Source of Variation in Arrests. Criminology 43: 1111-33. [CrossRef]

Pierce, Christopher T. 2006. Not only in my backyard but on my front stoop: The forgotten opinion of urbanites about concealed-carry in Missouri. Journal of Law and Policy 21: 407-29.

Ruddell, Rick, and Martin G. Urbina. 2004. Minority Threat and Punishment: A Cross-National Analysis. Justice Quarterly 21: 903-31. [CrossRef]

Skogan, Wesley G. 1995. Crime and racial fears of white Americans. The Annals of the American Academy of Political and Social Science 539: 59-71. [CrossRef]

Slovic, Paul, Baruch Fischhoff, and Sarah Lichtenstein. 1982. Why study risk perception? Risk Analysis 2: 83-93. [CrossRef]

Stolzenberg, Lisa, Stewart J. D’alessio, and David Eitle. 2004. A Multi-level Test of Racial Threat Theory. Criminology 42: 673-98. [CrossRef] 
Stroud, Angela. 2012. Good Guys with Guns: Hegemonic Masculinity and Concealed Handguns. Gender and Society 26: 216-38. [CrossRef]

Stults, Brian J., and Eric P. Baumer. 2007. Racial Context and Police Force Size: Evaluating the Empirical Validity of the Minority Threat Perspective. American Journal of Sociology 113: 507-46. [CrossRef]

Taylor, Marylee C. 1998. How White Attitudes vary with Racial Composition of Local Populations: Numbers Count. American Sociological Review 63: 512-35. [CrossRef]

Thompson, Carol, William Bankston, and Roberta St. Pierre. 1992. Parity and Disparity among Three Measures of Fear of Crime: A Research Note. Deviant Behavior 13: 373-89. [CrossRef]

Wang, Xia. 2012. Undocumented Immigrants as Perceived Criminal Threat: A Test of the Minority Threat Perspective. Criminology 50: 743-76. [CrossRef]

Wang, Xia, and Daniel P. Mears. 2010. Examining Direct and Interactive Effects of Changes in Racial and Ethnic Threat on Sentencing Decisions. Journal of Research in Crime and Delinquency 47: 522-57. [CrossRef]

Wilson-Doenges, Georjeanna. 2000. An exploration of sense of community and fear of crime in gated communities. Environment and Behavior 32: 597-611. [CrossRef]

Winfree, Thomas, and Howard Abadanski. 2017. Essentials of Criminological Theory, 4th ed. Long Grove: Waveland. Young, Robert L. 1986. Gender, region of socialization and ownership of protective firearms. Rural Sociology 51: 169-82.

(C) 2017 by the authors. Licensee MDPI, Basel, Switzerland. This article is an open access article distributed under the terms and conditions of the Creative Commons Attribution (CC BY) license (http:/ / creativecommons.org/licenses/by/4.0/). 